
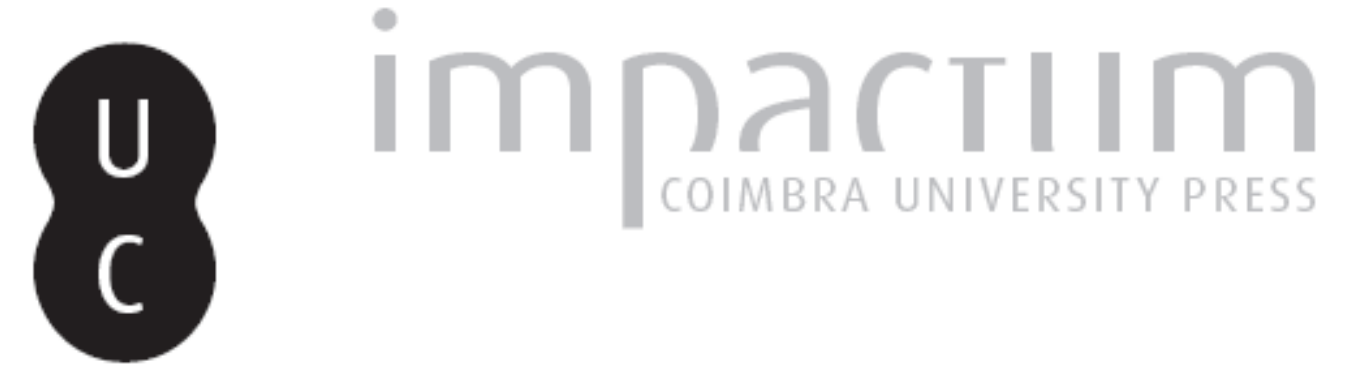

\title{
A small open economic growth model with imported goods, tourism, and terms of trade
}

\author{
Autor(es): $\quad$ Zhang, Wei-Bin
}

Publicado por: Imprensa da Universidade de Coimbra

URL persistente:

URl:http://hdl.handle.net/10316.2/42821

DOI:

DOI:https://doi.org/10.14195/2183-203X_44_4

Accessed : $\quad$ 26-Apr-2023 10:33:22

A navegação consulta e descarregamento dos títulos inseridos nas Bibliotecas Digitais UC Digitalis, UC Pombalina e UC Impactum, pressupõem a aceitação plena e sem reservas dos Termos e Condições de Uso destas Bibliotecas Digitais, disponíveis em https://digitalis.uc.pt/pt-pt/termos.

Conforme exposto nos referidos Termos e Condições de Uso, o descarregamento de títulos de acesso restrito requer uma licença válida de autorização devendo o utilizador aceder ao(s) documento(s) a partir de um endereço de IP da instituição detentora da supramencionada licença.

Ao utilizador é apenas permitido o descarregamento para uso pessoal, pelo que o emprego do(s) título(s) descarregado(s) para outro fim, designadamente comercial, carece de autorização do respetivo autor ou editor da obra.

Na medida em que todas as obras da UC Digitalis se encontram protegidas pelo Código do Direito de Autor e Direitos Conexos e demais legislação aplicável, toda a cópia, parcial ou total, deste documento, nos casos em que é legalmente admitida, deverá conter ou fazer-se acompanhar por este aviso.

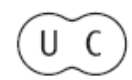




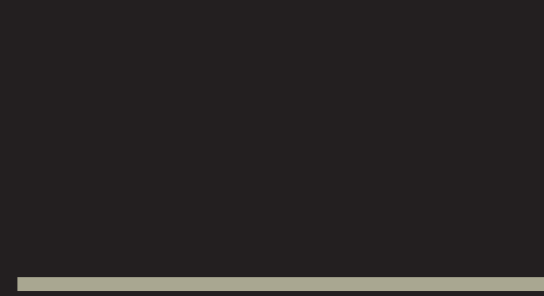

Francisco JosÉ VeigA

Forecast Errors in Prices and Wages: The Experience with Three Programme Countries

Manuel Correia de Pinho / Maria Manuel Pinho Esforço Fiscal em Portugal: Uma Avaliação no Período 1995-20I5

Patrícia Antunes / Pedro Lopes Ferreira / Lara N. Ferreira A Utilização da Experiência de Escolha Discreta na Valoração de Estados de Saúde

WEI-BIN ZHANG A Small Open Economic Growth Model with Imported Goods, Tourism, and Terms of Trade 


\title{
A Small Open Egonomic Growth Model with Imported Goods, TOURISM, AND TERMS OF Trade Wei-Bin Zhang
}

\begin{abstract}
This paper constructs an economic growth model of a small open economy with tourism and imported goods in a perfectly competitive economy. The study focuses on the effects of changes in terms of trade, with a preference for imported goods, on the dynamic paths of trade balance and economic growth. The basic framework for modelling a national economy is based on the Solow-Uzawa neoclassical growth model with Zhang's alternative approach to household behaviour. We build a nonlinear dynamic model with interdependence between economic growth, economic structure, tourism, prices, wealth and income. We provide a computational process to follow the motion of the economic system. Simulation is used to carry out a comparative dynamic analysis of the terms of trade, the propensity to consume imported goods, the rate of interest, the price elasticity of tourism, and the total productivity of the service sector. The comparative dynamic analysis provides some insights into the complexity of the tourism economy.
\end{abstract}

Keywords: tourism, price elasticity of tourism, terms of trade, small open economy.

JEL Classification: Z23; O41; F43

Acknowledgements: The author is grateful for the constructive comments of the anonymous referee. The author is also grateful for the financial support from the Grants-in-Aid for Scientific Research (C), Project No. 25380246, Japan Society for the Promotion of Science. 


\section{INTRODUGTION}

Tourism has become an important part of many economies (Andereck et al., 2005; MatarritaCascante, 2010; and Antonakakis, et al. 2015). Using data from the World Travel and Tourism Council, Chou (2013) describes the economic importance of tourism as follows: "The total impact of the industry is impressive. In 2011, it contributed to $9 \%$ of global GDP, a value of over US\$6 trillion, and accounted for 255 million jobs. Over the next ten years, this industry is expected to grow by an average of $4 \%$ annually. This will bring it to $10 \%$ of global GDP, or about US $\$ 10$ trillion. By 2022, it is anticipated that it will account for 328 million jobs, 1 in every 10 jobs on the planet." There are extensive studies about the relationship between tourism spending and economic growth for both developed and developing economies (e.g., Sinclair and Stabler, 1997; Luzzi and Flückiger, 2003; Hazari and Sgro, 2004; and Hazari and Lin, 2011). Most literature on relations between tourism and economic growth is empirical, even though there are a few mathematical models (e.g., Corden and Neary, 1982; and Copeland, 1991, 2012). The lack of theoretical research in the field is partly explained by the fact that introducing tourism into economic growth theory is analytically not easy. Different from other goods, tourism converts non-traded goods into tradable ones. This special character of tourism makes it difficult to use traditional theoretical frameworks directly to analyse the dynamic interdependence between tourism and economic growth. This study builds a dynamic model of tourism and economic structural change in a small open economic growth framework by applying an alternative approach to economic growth theory.

National economies can be affected by tourism in different ways. Tourism may compete for resources such as labour, capital and housing, with other sectors of the economy. Tourism also brings in income for the development of other economic activities. A tourism boom may cause congestion in transport systems and other public facilities. Empirical studies show an opposite relationship between a tourism boom and economic development (e.g., Balaguer and CantavellaJorda, 2002; Dritsakis, 2004; Durbarry, 2004; Oh, 2005; and Kim et al. 2006). Hazari and Sgro (1995) studied the dynamic relationship between tourism, capital accumulation, and the terms of trade. An increase in the international demand for tourism leads to a positive effect on long-run economic growth. Chao et al. (2006) find that an expansion of tourism can lead to capital decumulation. As pointed out by Chao et al. (2009), theoretical research on tourism has been mainly static. In order to comprehensively study possible effects of tourism on national economic development and economic structure, it is necessary to build a dynamic general equilibrium framework (Dwyer et al. 2004, and 
Blake et al. 2006). This study deals with interdependence between tourism and economic growth on the basis of Uzawa's two-sector growth model in the context of a small open economy. We examine the response of economic growth and trade balance in a small open two-sector economy with capital accumulation to changes in the price elasticity of tourism, the price of imported goods, and preference for imported goods.

An important issue in the literature of small open economies is the impact of disturbances such as global economic crisis, terms of trade and prices of inputs (e.g., Sachs, 1982; Svensson and Razin, 1983; and Matsuyama, 1987). A preference for foreign brands, for instance, could affect the economy's growth rate and structure. A widely discussed topic in the literature is the impact of a change in a country's terms of trade on the economy's growth rate (Mendosa, 1995; Kose, 2002; and Turnovsky and Chattopadhyay, 2003). This study examines effects of the preference for foreign goods on trade balance and long-run economic growth. We show that a stronger desire for foreign brands may hurt economic growth. To properly deal with interactions between growth, tourism, preference for foreign goods and trade balance, we build a genuine dynamic framework. As reviewed by Zeng and Zhu (2011), almost all the growth models in tourism economics are based on a small open economy (e.g., Obstfeld and Rogoff, 1996; Lane, 2001; Kollmann, 2001, 2002; Benigno and Benigno, 2003; and Galí and Monacelli, 2005). We follow this tradition. Our approach of introducing tourism into growth theory is influenced by Chao et al. (2006). A main difference between our approach and the model developed by Chao et al. (2006) is that this study is based on an alternative utility function proposed by Zhang (1993, 2005). This paper is an extension of Zhang's model (Zhang, 2012). The main difference between this paper and Zhang's model is that we now add the imported goods and terms of trade into Zhang's growth model with tourism. The rest of the paper is organised as follows: Section 2 defines the basic model; Section 3 provides a computational procedure to plot the motion of the economy and simulates the model; Section 4 examines effects of changes in some parameters on the economic system over time; Section 5 concludes the study. The appendix gives the proof of the main results in Section 3.

\section{THE GROWTH MODEL WITH TOURISM}

The model is a combination of the basic features of three well-known models, Solow's growth model, Uzawa's two-sector growth model (Uzawa, 1961), and the growth models with tourism. 
Following Chao et al. (2009), we consider an economy that is small and open and produces two goods: an international industrial good and national services. National services are "tradable" in the sense that foreign tourists come to visit the country and consume services. This study emphasises changes in the propensity to save and to consume imported goods, and in the terms of trade. Following the model by Eicher et al. (2008), we include another good, called an imported good. This good is not produced by the economy, but it is consumed by the domestic consumers. The introduction of this good enables us to consider the impact of domestic households' preference for goods which cannot be produced by the domestic economy. A stronger desire, for instance, for foreign luxury goods or special agricultural products could affect the domestic economic structure. There are two types of consumer, domestic households and foreign tourists. To simplify the analysis, we assume that domestic households consume the two goods and services, while foreign tourists consume only services. Tourism converts services into an exportable commodity. In our model, the economy freely imports goods, and freely exports goods. The price of the industrial good is unity. Capital depreciates at a constant exponential rate $\delta_{k}$. We assume that the economy is too small to affect the world interest rate $r^{*}$ and price of imported goods $p_{Z}$. We assume that $r^{*}$ and $p_{Z}$ are constant. The households hold wealth and land and receive income from wages, land rent, and interest payments on wealth. Land is only for residential and service use.

The production sector technologies are characterised by constant returns to scale. All markets are perfectly competitive and capital and labour are completely mobile between the two sectors. Capital is perfectly mobile in international markets and we neglect the possibility of emigration or/and immigration. We assume that the population $N$ is constant and homogeneous. We use subscript indices, $i$ and $s$, to denote respectively the industrial and service sectors. Let $K_{j}(t)$ and $N_{j}(t)$ stand for the capital stocks and labour force employed by sector $j, j=i, s$, at time $t$. We use $F_{j}(t)$ to represent the output level of sector $j$.

\section{THE INDUSTRIAL SECTOR}

The production function of the industrial sector is given by

$$
F_{i}(t)=A_{i} K_{i}^{\alpha_{i}}(t) N_{i}^{\beta_{i}}(t), \alpha_{i}, \beta_{i}>0, \alpha_{i}+\beta_{i}=1,
$$


where $A_{i}, \alpha_{i}$, and $\beta_{i}$ are parameters. Labour and capital earn their marginal products, and firms earn zero profits. The wage rate $w(t)$ is determined in the domestic labour market. The marginal conditions for the industrial sector are

$$
r_{\delta}=\alpha_{i} A_{i} k_{i}^{-\beta_{i}}(t), w(t)=\beta_{i} A_{i} k_{i}^{\alpha_{i}}(t),
$$

where $k_{i}(t) \equiv K_{i}(t) / N_{i}(t)$ and $r_{\delta} \equiv r^{*}+\delta_{k}$. From (2) we solve

$$
k_{i}=\left(\frac{\alpha_{i} A_{i}}{r_{\delta}}\right)^{1 / \beta_{i}}, w=\beta_{i} A_{i} k_{i}^{\alpha_{i}} .
$$

We consider $k_{i}$ and $w$ as functions of $r^{*}$.

\section{THE SERVICE SECTOR}

Service production needs three inputs, capital $K_{s}(t)$, labour force $N_{s}(t)$, and land $L_{s}(t)$. The production function of the service sector is

$$
F_{s}(t)=A_{s} K_{s}^{\alpha_{s}}(t) N_{s}^{\beta_{s}}(t) L_{s}^{\gamma_{s}}(t), \alpha_{s}, \beta_{s}, \gamma_{s}>0, \alpha_{s}+\beta_{s}+\gamma_{s}=1,
$$

where $A_{s}, \alpha_{s}, \beta_{s}$, and $\gamma_{s}$ are parameters. We use $p(t)$ and $R(t)$ to stand respectively for the price of the service and the land rent. The marginal conditions for the service sector are

$$
\begin{aligned}
& r_{\delta}=\alpha_{s} A_{s} p(t) k_{s}^{\alpha_{s}-1}(t) l_{s}^{\gamma_{s}}(t), \quad w=\beta_{s} A_{s} p(t) k_{s}^{\alpha_{s}}(t) l_{s}^{\gamma_{s}}(t), \\
& R(t)=\gamma_{s} A_{s} p(t) k_{s}^{\alpha_{s}}(t) l_{s}^{\gamma_{s}-1}(t),
\end{aligned}
$$

where

$$
k_{s}(t) \equiv \frac{K_{s}(t)}{N_{s}(t)}, l_{s}(t) \equiv \frac{L_{s}(t)}{N_{s}(t)} .
$$

From (5) we have

$$
k_{s}=\frac{\alpha_{s} w}{\beta_{s} r_{\delta}} .
$$

We can consider $k_{s}$ as a function of $r^{*}$. 


\section{FULL EMPLOYMENT OF GAPITAL AND LABOUR}

The total capital stock employed by the country $K(t)$ is employed by the two sectors. The full employment of labour and capital is represented by

$$
K_{i}(t)+K_{s}(t)=K(t), N_{i}(t)+N_{s}(t)=N .
$$

We rewrite the above equations as

$$
k_{i} N_{i}(t)+k_{s} N_{s}(t)=K(t), N_{i}(t)+N_{s}(t)=N .
$$

The capital intensity of the two sectors, $k_{i}$ and $k_{s}$, are uniquely determined in (3) and (4) as functions of the fixed rate of interest. From (7), we have

$$
N_{i}(t)=\left(K(t)-k_{s} N\right) k_{0}, N_{s}(t)=\left(k_{i} N-K(t)\right) k_{0},
$$

where $k_{0} \equiv\left(k_{i}-k_{s}\right)^{-1}$. We require $k_{0} \neq 0$. The labour distribution is a unique function of the total capital used by the country.

\section{DEMAND FUNCTION OF FOREIGN TOURISTS}

Following Schubert and Brida (2009), we use the following iso-elastic tourism demand function

$$
D_{T}(t)=a(t) y_{f}^{\phi}(t) p^{-\varepsilon}(t),
$$

where $y_{f}(t)$ stands for the disposable income of foreign countries, $\phi$ and $\varepsilon$ are respectively the income and price elasticities of tourism demand. We consider $a(t)$ dependent on many conditions, such as environment (e.g., crime rates, pollutants and congestion) and infrastructure (airports and transport systems). We assume that tourists pay the same price for services as the domestic household does. We do not consider other features of the tourism industry which have important effects on pricing (e.g., Marin-Pantelescu and Tigu, 2010; Stabler, et al., 2010).

\section{BEHAVIOUR OF DOMESTIC HOUSEHOLDS}

We now describe the behaviour of domestic households on the basis of the approach by Zhang (1993). The implications of this approach are similar to those in the Keynesian consumption function and models based on the permanent income hypothesis, which are empirically much more valid than 
the approaches in the Solow model or the Ramsey model. The approach is discussed at length by Zhang (2005, 2008). Zhang (2005) has also examined in detail the relations between his approach and the Solow growth theory, the Ramsey growth theory, the permanent income hypothesis, and the Keynesian consumption function. It can be shown that the behaviour generated by the traditional approaches can also be observed in Zhang's approach if certain patterns of preference changes are specified. As it assumes a fixed proportion of disposable income (which is the current income in Zhang's approach) is saved, the Solow model does not take account of how changes in wealth affect saving behaviour. The traditional Keynesian consumption function lacks a rational microfoundation. The approach becomes less effective when one has to deal with multiple goods and saving in a consistent manner. The Ramsey approach is based on the assumption that the utility is additional for the same person over that person's life time. There are extensive studies on the limitations of this formation. A comprehensive survey of the literature is given by Frederick et al. (2002). Zhang proposes an alternative approach to household behaviour by taking account of the valid points and overcoming the shortcomings in the traditional approaches.

Let $L$ denote the total land available for service production and residential use. Each household obtains income from land ownership, wealth and wages. To simplify the model, we assume that the land is equally owned by the population. The revenue from land is equally shared among the population. The total land revenue is $L R(t)$. The income from land per household $\bar{r}(t)$ is $\bar{r}(t)=L R(t) / N$. The household chooses the lot size, consumption levels of industrial goods, imported goods and services, and how much to save. The current income is

$$
y(t)=r^{*} \bar{k}(t)+w+\bar{r}(t),
$$

where $\bar{k}(t)$ is wealth held per household. We call $y(t)$ the current income in that it comes from consumers' wages and current earnings from ownership of wealth. The sums of income that consumers are using for consuming and saving are not necessarily equal to the current income because they can sell wealth to pay for current consumption, for instance, if the current income is not sufficient for the purpose. The total value of the wealth that a consumer can sell to purchase goods and to save is equal to $p_{i}(t) \bar{k}(t)$, with $p_{i}(t)=1$ at any $t$, where $p_{i}(t)$ is the price of the industrial good. Here, we assume that selling and buying wealth can be done instantaneously without any transaction cost. 
The disposable income at any point in time is

$$
\hat{y}(t)=y(t)+\bar{k}(t) \text {. }
$$

Disposable income is used for saving and consumption. At time $t$ the consumer has the total amount of income equalling $\hat{y}$ to distribute between consuming and saving. In the growth literature, for instance in the Solow model, the saving comes out of the current income $y(t)$, while in this study the saving comes out of the disposable income, which is dependent both on the current income and wealth.

At each point in time, a consumer distributes the total available budget between lot size $l(t)$, consumption of services $c_{s}(t)$, industrial goods $c_{i}(t)$, imported goods $c_{Z}(t)$, and saving $s(t)$. The budget constraint is

$$
R(t) l(t)+p(t) c_{s}(t)+c_{i}(t)+p_{Z} c_{Z}(t)+s(t)=\hat{y}(t) .
$$

Equation (12) means that the consumption and saving exhaust the consumer's disposable income. We assume that utility level $U(t)$ of the household is dependent on $l(t), c_{s}(t), c_{i}(t)$ and $s(t)$ as follows:

$$
U(t)=\theta l^{\eta_{0}}(t) c_{s}^{\gamma_{0}}(t) c_{i}^{\xi_{0}}(t) c_{Z}^{\varsigma_{0}}(t) s^{\lambda_{0}}(t), \eta_{0}, \gamma_{0}, \xi_{0}, \varsigma_{0}, \lambda_{0}>0,
$$

in which $\eta_{0}, \gamma_{0}, \xi_{0}, \varsigma_{0}$ and $\lambda_{0}$ are the elasticities of utility with regard to lot size, services, industrial goods, imported good, and saving. We call $\eta_{0}, \gamma_{0}, \xi_{0}, \varsigma_{0}$ and $\lambda_{0}$ propensities to consume the lot size, to consume services, to consume industrial goods, to consume imported goods, and to hold wealth, respectively. The time horizon of the consumer's decisions is not explicitly mentioned in this utility function. As argued in Zhang (2005), the time horizon can be taken into account by making the propensities endogenous. Maximizing $U(t)$ subject to (12) yields

$$
l(t)=\frac{\eta \hat{y}(t)}{R(t)}, c_{s}(t)=\frac{\gamma \hat{y}(t)}{p(t)}, c_{i}(t)=\xi \hat{y}(t), c_{Z}(t)=\frac{\varsigma \hat{y}(t)}{p_{Z}}, s(t)=\lambda \hat{y}(t),
$$

where

$$
\begin{aligned}
& \eta \equiv \rho \eta_{0}, \gamma \equiv \rho \gamma_{0}, \xi \equiv \rho \xi_{0}, \varsigma \equiv \rho \varsigma_{0}, \lambda \equiv \rho \lambda_{0}, \\
& \rho \equiv \frac{1}{\eta_{0}+\gamma_{0}+\xi_{0}+\varsigma_{0}+\lambda_{0}} .
\end{aligned}
$$


We assume that saving and transactions are conducted without any barriers. According to the definition of $s(t)$, the wealth accumulation of the household is

$$
\dot{\bar{k}}(t)=s(t)-\bar{k}(t) \text {. }
$$

This equation states that the change in wealth equals saving minus dissaving.

\section{FULL USE OF LAND}

Land is used for the residential purposes and service production

$$
l(t) N+L_{s}(t)=L
$$

\section{BALANCE OF DEMAND AND SUPPLY FOR SERVIÇES}

The equilibrium condition for services is

$$
c_{s}(t) N+D_{T}(t)=F_{s}(t)
$$

We define the GDP by: $Y(t)=F_{i}(t)+p(t) F_{s}(t)$.

\section{TRADE BALANCE}

Let $\bar{K}(t)$ stand for the total wealth owned by the country's population, that is, $\bar{K}(t)=\bar{k}(t) N$. The capital owned by the population is not necessarily equal to the level of capital stocks employed by the country. We use $E(t)$ to denote the balance of trade. We have

$$
E(t)=r^{*}(\bar{K}(t)-K(t))
$$

We have thus built the dynamic growth model with endogenous wealth, consumption, and tourism.

\section{THE DYNAMicS OF THE NATIONAL EcONOMY}

The appendix shows that the motion of the economic system is determined by a single differential equation. The following lemma shows how we can determine the motion of all the variables in the dynamic system. 


\section{LEMMA}

The variables, $k_{i}, k_{s}$, and $w$ are uniquely determined as functions of $r^{*}$ by (3) and (4). The motion of the land rent is determined by

$$
\dot{R}(t)=\bar{\Lambda}(R(t))
$$

in which $\bar{\Lambda}(t)$ is a function of $R(t)$ defined in the appendix. We determine all the other variables as functions of $R(t)$ as follows: $\bar{k}(t)$ by $(\mathrm{A} 12) \rightarrow \bar{K}(t)=\bar{k}(t) N \rightarrow K(t)$ by (A11) $\rightarrow p(t)$ by (A9) $\rightarrow K_{i}(t)$ and $K_{s}(t)$ by $(\mathrm{Al}) \rightarrow N_{i}(t)$ and $N_{s}(t)$ by $(\mathrm{Al}) \rightarrow D_{T}(t)$ by $(8) \rightarrow \hat{y}(t)$ by $(\mathrm{A} 4) \rightarrow$ $l(t), c_{i}(t), c_{s}(t), c_{Z}(t)$, and $s(t)$ by $(13) \rightarrow L_{s}(t)$ by $(15) \rightarrow F_{i}(t)$ by $(1) \rightarrow F_{s}(t)$ by $(4)$.

The lemma implies that the motion of economic system at any point in time can be uniquely described as functions of the land rent and the other exogenous variables (the rate of interest, land resource, technology, and preference). In Turnovsky's (1996) model for a small open economy domestic capital accumulation involves convex adjustment costs. The equilibrium growth rates of domestic capital and consumption are found to be largely independent. The equilibrium growth rate of domestic capital is determined by production conditions. The equilibrium growth rate of consumption is determined primarily by tastes. Turnovsky's model has a single production sector and the production function is explicitly dependent only on capital, as follows: $F(t)=a K(t)$ where $F(t)$ is the output of the sector, $K(t)$ is the capital employed by the domestic sector, and $a$ is a parameter. In our model, the capital intensity (rather than the capital stock, as in the Turnovsky model) and the wage rate are determined by the internationally fixed interest rate and production conditions. This result derives from the assumption that capital is internationally freely mobile and the interest rate is fixed. Nevertheless, the total output levels, the capital stocks employed by the economy, and the economic production structure are determined not only by the production conditions and the international rate of interest, but also by tastes. This results from our modelling structure, which has economic structures as endogenous variables. As preference determines demand and demand affects the labour distribution, the variables just mentioned are dependent on the preference. Moreover, consumption is not only determined by preferences but it is also related to the rate of interest and the production conditions. This is because the rate of interest and the production conditions affect the disposable income. 
Eicher et al. (2008) observe, "Previous authors have specified the borrowing cost to increase with the nation's level of debt. This specification, together with a constant rate of time preference and inelastic labor supply, implies that terms of trade shocks have no dynamic effects. The only response is that consumption fully adjusts instantaneously, with the current account remained unchanged." Although it is formed in an alternative framework, our model also predicts similar conclusions. To explain this, we first note that from the appendix we know that the disposable income $\hat{y}(t)$ is not affected by the price of imported goods $p_{Z}$. The price affects the system only through the equation, $p_{Z} c_{Z}(t)=\varsigma \hat{y}(t)$. From this equation we have

$$
\frac{d c_{Z}(t)}{c_{Z}(t)}=-\frac{d p_{Z}}{p_{Z}} \text {. }
$$

This implies that the rise in the price (terms of trade) has no effect on the other variables in the dynamic system, except for the purchase of imported goods. According to Harberger (1950) and Laursen and Metzler (1950) a deterioration in the terms of trade would reduce real income, thereby reducing saving and investment to cause a deterioration of the current account balance. Our analysis does not predict the Harberger-Laursen-Metzler effect. This result depends on the assumed CobbDouglas utility function. From the above equation we see that a deterioration in the terms of trade causes the same proportional reduction in the consumption of imported goods. Accordingly, there is no Harberger-Laursen-Metzler effect in our model. It should be noted that the Harberger-LaursenMetzler effect might occur if we use other forms of utility function.

As it is difficult to explicitly interpret the analytical results, we simulate the model. We specify the parameters as follows:

$$
\begin{aligned}
& r^{*}=0.05, p_{Z}=4, \delta_{k}=0.05, N=10, L=1, A_{i}=1.4, A_{s}=1.1, \\
& \alpha_{i}=0.31, \alpha_{s}=0.22, \beta_{s}=0.58, \lambda_{0}=0.62, \xi_{0}=0.15, \gamma_{0}=0.07, \\
& \eta_{0}=0.07, \varsigma_{0}=0.03, a=1, y_{f}=5, \phi=1.8, \varepsilon=1.3 .
\end{aligned}
$$

The rate of interest is fixed at 5 per cent and the population is 10 . The land is unity. The propensity to save is 0.62 . The propensity to consume is 0.10 . The propensities to consume services, imported goods, and housing are respectively $0.07,0.03,0.07$. The price of imported goods is 4 . Some empirical studies show that income elasticity of tourism demand is well above unity 
(Syriopoulos, 1995; Lanza et al., 2003). According to Lanza et al. (2003), the price elasticity is in the range from 1.03 to 1.82 and income elasticities are in the range from 1.75 to 7.36 . There are other studies on elasticities of tourism (e.g., Gaŕin-Mũnos, 2007).

Following the lemma, we calculate the time-independent variables as follows:

$$
k_{i}=8.39, k_{s}=7.09, w=1.87 .
$$

We choose the initial condition with $R(0)=12$. We plot the motion of the dynamic system in Figure 1. As the initial value of the land is fixed higher than its long-term equilibrium value, the land rent falls over time. As the price falls, demand of tourism rises. The lot size falls and the land used by the service sector rises. The consumption level of goods and services is reduced. The consumption level of imported goods fall as the disposable income falls. The output of the industrial sector rises, while the output of the service sector falls. The labour force is shifted from the service sector to the industrial sector. The capital stocks employed by the economy and the industrial sector are slightly higher. The capital stock employed by the service sector falls slightly.

Figure 1. The Motion of the National Economy
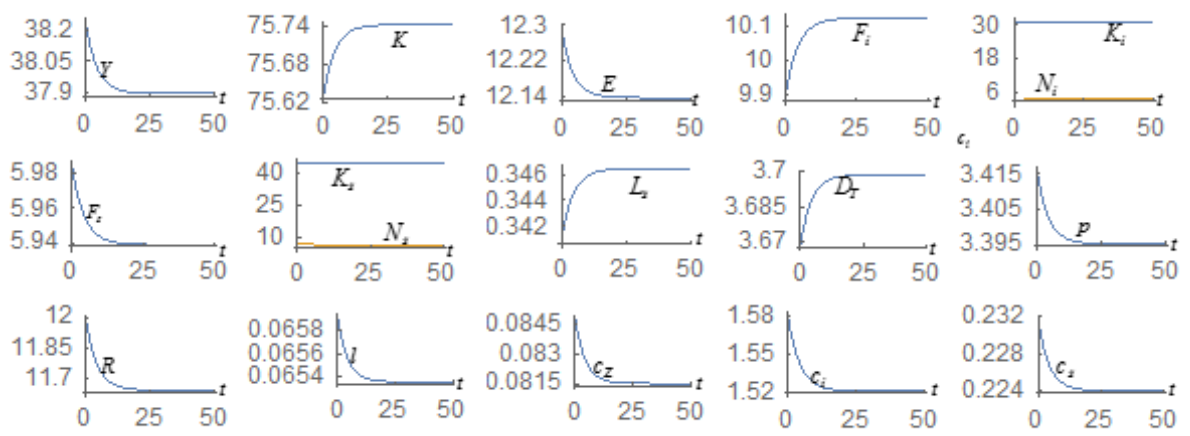
Figure 1 shows how the system approaches an equilibrium point. We calculate the equilibrium values of the variables as follows

$$
\begin{aligned}
& p=3.4, R=11.64, \quad Y=37.9, \quad E=12.14, K=75.74, \bar{K}=67.38, \\
& D T=3.7, \quad N_{i}=3.74, N_{s}=6.26, \quad K_{i}=31.38, \quad K_{s}=44.36, \\
& L_{s}=0.35, \quad F_{i}=10.12, F_{s}=5.94, \quad c_{i}=1.52, \quad c_{s}=0.22, \\
& c_{Z}=0.081, \quad l=0.065 .
\end{aligned}
$$

The eigenvalue at the equilibrium point is -0.23 . Accordingly the unique equilibrium point is stable. The stability is important as it ensures that we can effectively conduct comparative dynamic analysis.

\section{Comparative Dynamic Analysis}

The previous section plotted the changes of the variables. This section examines how changes in some parameters affect the national economy. As we have shown how to simulate the motion of the system, the comparative dynamic analysis is straightforward. We introduce a variable $\bar{\Delta} x(t)$ to stand for the percentage change rate of the variable $x(t)$ due to the change in a parameter value.

\section{A RISE IN THE PROPENSITY TO CONSUME IMPORTED GOODS}

First, we examine the impact of the following change in the propensity to consume imported goods: $\varsigma_{0}: 0.03 \Rightarrow 0.04$. We have $\bar{\Delta} k_{i}=\bar{\Delta} k_{s}=\bar{\Delta} w=0$. The change has no impact on the capital intensity and the wage rate. As these variables are dependent only on the interest rate and technologies, the change in the preference has no impact on their values. The changes in the time-dependent variables are plotted in Figure 2. The demand for imported goods is increased. The economy spends more money on the consumption of foreign goods and less on industrial goods and services. The fall in domestic demand for the local services reduces the price of services. The fall in the price attracts more foreign tourists. As the fall of service consumption by the population dominates the rise by foreign tourists, the total service production is reduced. In association with the falls in service supply and price of services, some labour force is shifted from the service sector to the industrial sector. 
Initially the rise in wealth is faster than the rise in the total capital employed by the country. The trade balance is improved, but soon the wealth falls and the total capital employed by the country rises slightly. The trade balance deteriorates. In association with the fall in the price of services, the industrial sector increases the scale of production. As a rise in the propensity to consume imported goods also implies a fall in the (relative) propensity to consume housing, the lot size is reduced, which results in a fall in the land rent. Some of the land is shifted from the housing market to the service sector. As the value produced by the service sector is lower than that produced by the industrial sector, GDP falls over time.

Figure 2. A Rise in the Propensity to Consume Imported Goods

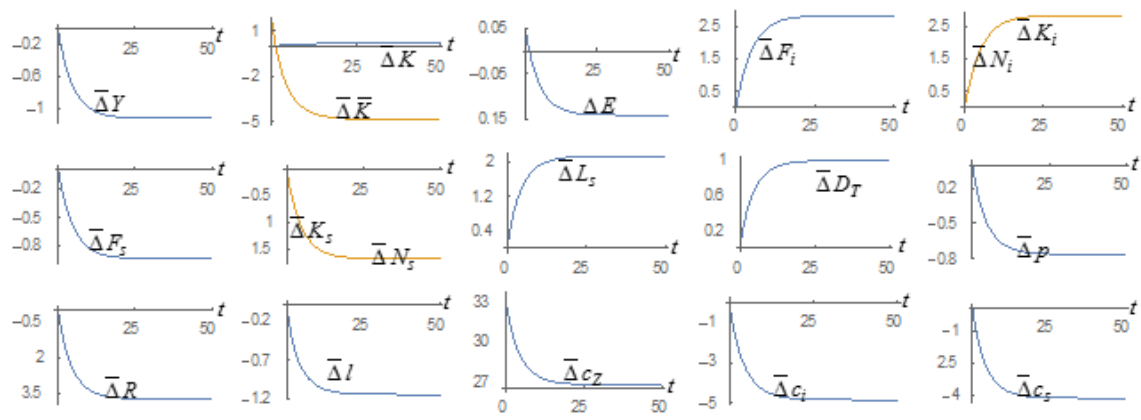

\section{A RISE IN THE INTEREST RATE}

We now allow the rate of interest to be changed as follows: $r^{*}=0.05 \Rightarrow 0.06$. The rise in capital cost causes the capital intensity and wage rate to fall as follows:

$$
\bar{\Delta} k_{i}=\bar{\Delta} k_{s}=-12.9, \bar{\Delta} w=-4.2 \text {. }
$$

The net result in the rise of the interest rate and fall in capital intensity leads to the fall in the wage rate. We plot the changes in the time-dependent variables in Figure 3. The two sectors use less capital in response to the rising cost of capital. The capital stock employed by the national economy is reduced. The net consequence of reduced wage income and increased rate of interest is a slight fall in the wealth. The price of services and the land rent both increase over time. There are more foreign visitors as the country's economic attractiveness improves. The output of the industrial sector falls in response to the 
higher production cost, while the output level of the service sector is slightly increased as a net result of increased demand and production cost. Some of the labour force is shifted from the industrial sector to the service sector. The GDP falls over time, but the trade balance is improved. The lot size is slightly reduced. The household consumes more services and less industrial and imported goods.

Figure 3. An Increase in the Rate of Interest
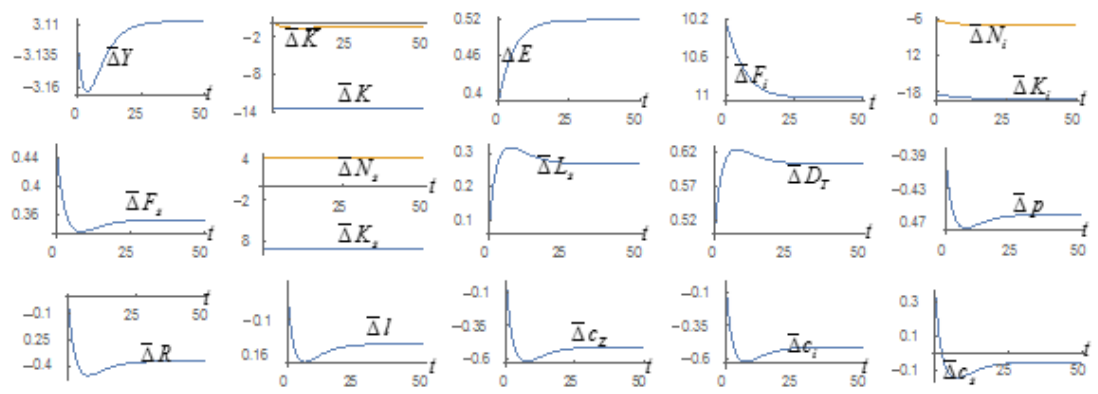

\section{AN IMPROVEMENT IN GLOBAL ECONOMIC CONDITIONS}

As the country is dependent on tourism, changes in global economic conditions should affect the national economy. We allow the foreign income to be enhanced as follows: $y_{f}=5 \Rightarrow 5.1$. Figure 4 plots the changes in the time-dependent variables. The capital intensity and wage rate are not affected. More foreigners come to visit the country. The boom in tourism causes the price of services and output of the service sector to rise. The labour, capital, and land inputs employed by the service sector are all increased. More foreign visitors reduce the lot size and increase the land used by the service sector. The income of the household is initially reduced but increases later on. The consumption level of goods and services, wealth level, and consumption of imported goods are all reduced initially but increase in the long term. The trade balance is improved. An improvement in the global income reduces the living conditions and wealth of the domestic household in the short term but improves these variables in the long term. According to Harzri and Sgro (1995) an increase in the international tourism has a positive effect on long-run economic growth. Our result shows that this conclusion is true in the long term, but not necessarily true in the short term. Similarly, their model 
shows that for a small open economy the growth in tourist consumption of services increases welfare. Our simulation demonstrates that this conclusion is valid in the long term, but not necessarily true in the short term. We get this "new insight" because our model explicitly shows transitional processes in the economic dynamics. As demonstrated by Chao et al. (2006), an expansion of tourism can result in capital decumulation in a two-sector dynamic model with a capital-generating externality. Our simulation demonstrates the same conclusion without any externality.

Figure 4. An Improvement in Economic Conditions of the Global Economy
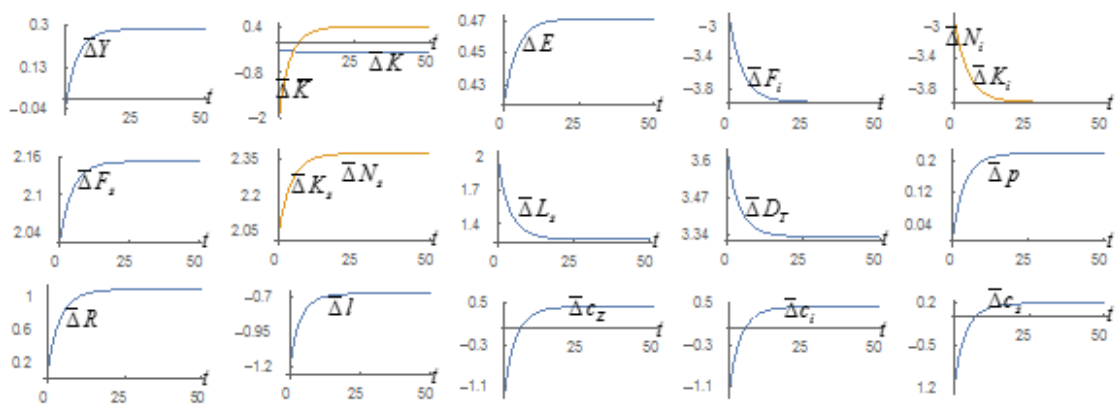

\section{A RISE IN THE PRICE ELASTICITY OF TOURISM}

Many factors affect the price elasticity of tourism. For instance, fast development of other countries' tourist industries may make the home country more elastic. We now change the price elasticity as follows: $\varepsilon=1.3 \Rightarrow 1.4$. The capital intensity and wage rate are not affected. The changes in the time-dependent variables are plotted in Figure 5. A rise in price elasticity reduces the tourist demand and the price of services. The national trade balance deteriorates as a consequence of the lower number of tourists. The output of the industrial sector is increased as some of labour force is shifted from the service sector to the industrial sector. The lot size rises, but the land input of the service sector is reduced. GDP rises initially but soon falls. The consumption levels of industrial goods, imported goods and services and wealth level rise initially but fall in the long term. 
Figure 5. A Rise in the Price Elasticity of Tourism
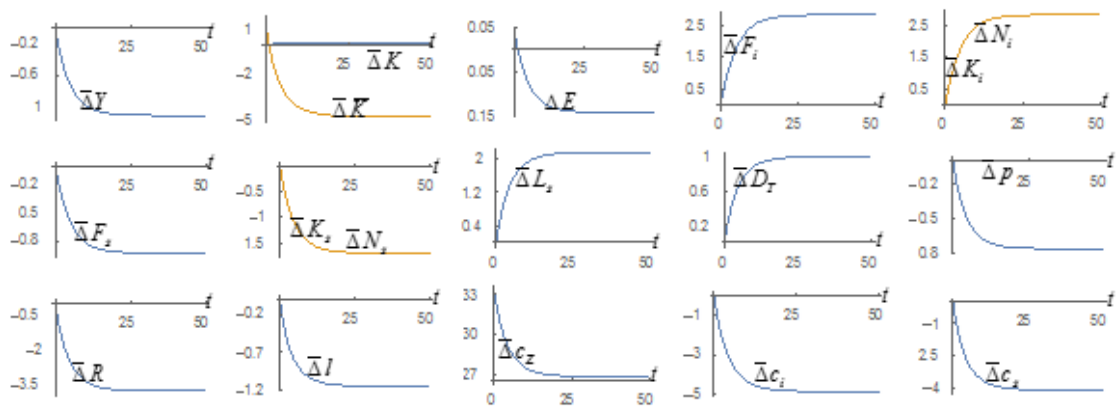

\section{A RISE IN TOTAL PRODUCTIVITY OF THE SERVICE SECTOR}

We now change the total productivity of the service sector as follows: $A_{s}=1.1 \Rightarrow 1.2$. There is no impact on the capital intensity and wage rate. The changes in the time-dependent variables are plotted in Figure 6. The output level of services is increased and the price of services falls. The net impact of the rise in the output of the service sector and the fall in the output of the industrial sector is that the GDP is almost not affected. Some of labour force is shifted from the industrial sector to the service sector. The lot size is reduced and the land input employed by the service sector is increased. The consumption level of services increases in association with the fall in the price. The consumption levels of industrial and imported goods are slightly affected. The trade balance is improved. Wealth falls initially but rises in the long term. As the price of services falls, there are more foreign visitors. 
Figure 6. A Rise in Total Productivity of the Service Sector
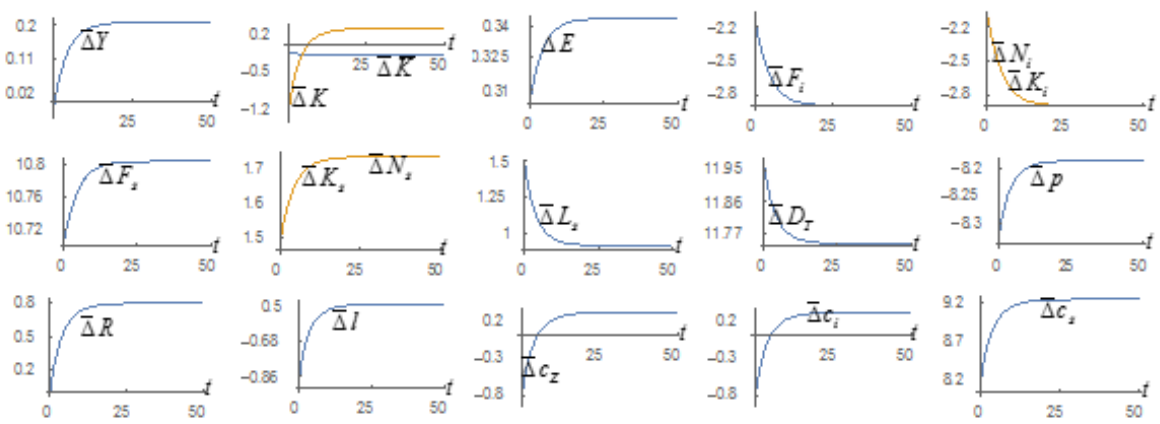

\section{A RISE IN TOTAL PRODUCTIVITY OF THE INDUSTRIAL SECTOR}

We now allow the total productivity of the industrial sector to be enhanced as follows: $A_{i}: 1.4 \Rightarrow 1.5$. The effects on the capital intensity and wage rate are as follows

$$
\bar{\Delta} k_{i}=\bar{\Delta} k_{s}=\bar{\Delta} w=10.52 \text {. }
$$

The changes in the time-dependent variables are plotted in Figure 7. It is interesting to note that Baumol (1967) builds a two-sector growth model of a closed economy. Baumol discusses different implications of technological changes in the manufacturing sector. A main conclusion from his model is that technological advances in the manufacturing sector will enhance service prices and the output of the service sector. Our model predicts a rise in the service price and a fall in the service sector's output. The conclusions arrived at by our model and Baumol's analysis differ because our model is for an open economy and Baumol's is for a closed economy. 
Figure 7. A Rise in Total Productivity of the Industrial Sector
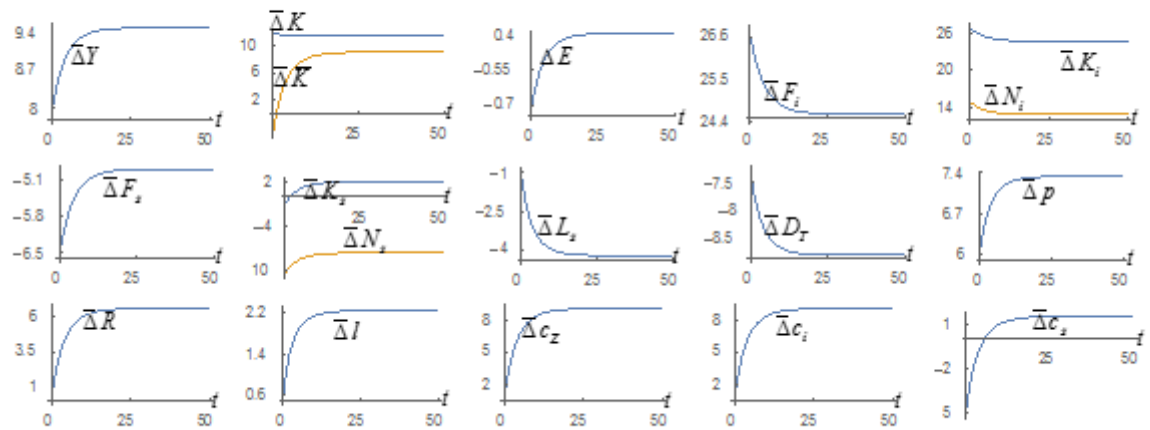

\section{Conclusions}

This paper has described an economic growth model of a small open economy with tourism and imported goods in a perfectly competitive economy. The study focuses on the effects of changes in the terms of trade, with a preference for imported goods, on the dynamic paths of trade balance and economic growth. The national economy consists of the two sectors. Following the traditional literature on small open economies, we assume that the rate of interest is fixed in the international market. The production side is the same as in neoclassical growth theory. We applied the utility function proposed by Zhang to determine saving and consumption. We simulated the model and demonstrated that the system has a unique stable equilibrium point. We examined the effects of changes on the terms of trade, the propensity to consume imported goods, the rate of interest, the price elasticity of tourism, and the total productivity of the service sector. The comparative dynamic analysis provides some important insights.

We may also get hints on policy implications from our analysis. For instance, we have shown that a stronger preference for imported goods harms national economic growth. It may thus be desirable for governments to weaken the preference for foreign goods or to tax them. The government could also improve safety, infrastructure elements and other amenities to reduce the price elasticity of 
tourism demand. It should be noted that the model contains with many strict assumptions. We may extend and generalise the model in different directions. For instance, it is important to study the economic dynamics when utility and production functions take on other functional forms. We do not consider the possibility of domestic households travelling to other countries. Monetary issues such as exchange rates and inflation policies are important for understanding trade issues, and we also neglect tariffs and other taxes.

\section{APPENDIX: PROVING THE LEMMA}

We have shown that $k_{i}, w$, and $k_{s}$ are determined as functions of $r^{*}$, which is fixed in the international market. From $K_{j}=k_{j} N_{j}$ and (8), we have

$$
K_{i}=\left(K-k_{s} N\right) k_{0} k_{i}, K_{s}=\left(k_{i} N-K\right) k_{0} k_{s},
$$

where we omit the time variable in the expressions. From (5), we solve

$$
R=\frac{w_{s} N_{s}}{L_{s}},
$$

where we also use $l_{s}=L_{s} / N_{s}$ and $w_{s} \equiv w \gamma_{s} / \beta_{s}$. Insert (A2) in (15)

$$
l N+\frac{w_{s} N_{s}}{R}=L
$$

From the definition of $\hat{y}$, we have

$$
\hat{y}=\left(1+r^{*}\right) \bar{k}+w+\frac{R L}{N} .
$$

From (A4) and $l=\eta \hat{y} / R$ in (13)

$$
l=\frac{\left(1+r^{*}\right) \eta \bar{k}+\eta w}{R}+\frac{\eta L}{N} .
$$

Insert this equation in (A3)

$$
\left(1+r^{*}\right) \eta \bar{k}+\eta w+\frac{w_{s} N_{s}}{N}=(1-\eta) \frac{L}{N} R .
$$

From $r^{*}+\delta_{k}=\alpha_{s} p F_{s} / K_{s}$ and (16) we have 


$$
c_{s} N+D_{T}=\frac{r_{\delta} K_{s}}{\alpha_{s} p} .
$$

Insert $c_{s}=\gamma \hat{y} / p$ in (A6)

$$
\gamma \hat{y} N+p D_{T}=\frac{r_{\delta} K_{s}}{\alpha_{s}} .
$$

Insert (A4) into this equation

$$
\left(\left(1+r^{*}\right) \bar{k}+w+\frac{R L}{N}\right) \gamma N+a y_{f}^{\phi} p^{1-\varepsilon}=\frac{r_{\delta} K_{s}}{\alpha_{s}},
$$

where we also use (9). We now discuss two cases, $\varepsilon=1$ and $\varepsilon \neq 1$, separately.

In $\varepsilon=1$, (A7) becomes

$$
\left(\left(1+r^{*}\right) \bar{k}+w+\frac{R L}{N}\right) \gamma N+a y_{f}^{-\phi}=\frac{r_{\delta} K_{s}}{\alpha_{s}} .
$$

From (A5) and (A8), we delete $R$ and get an equation which gives the relation between $\bar{k}$ and $K$. As discussed in the other case, we can determine a differential equation in terms of $K$.

We now examine $\varepsilon \neq 1$. From (5) we have

$$
p=\frac{w R^{\gamma_{s}}}{\beta_{s} A_{s} k_{s}^{\alpha_{s}} w_{s}^{\gamma_{s}}}
$$

where we also use $l_{s}=w_{s} / R$ from (A2). Insert (A9) in (A7)

$$
\left(1+r^{*}\right) \gamma N \bar{k}+\gamma N w+\gamma R L+a y_{f}^{\phi}\left(\frac{w R^{\gamma_{s}}}{\beta_{s} A_{s} k_{s}^{\alpha_{s}} w_{s}^{\gamma_{s}}}\right)^{1-\varepsilon}=\frac{r_{\delta} K_{s}}{\alpha_{s}} .
$$

Substituting $N_{s}=\left(k_{i} N-K\right) k_{0}$ from (8) into (A5) and $K_{s}=\left(k_{i} N-K\right) k_{0} k_{s}$ from (A1) into (A10) respectively yields

$$
\begin{aligned}
& \left(1+r^{*}\right) \eta N \bar{k}-w_{s} k_{0} K=\bar{\Psi}, \\
& \left(1+r^{*}\right) \gamma N \bar{k}+\frac{r_{\delta} k_{0} k_{s} K}{\alpha_{s}}=\widetilde{\Psi},
\end{aligned}
$$

where 


$$
\begin{aligned}
& \bar{\Psi}(R(t))=(1-\eta) L R-\eta N w-k_{i} w_{s} k_{0} N \\
& \widetilde{\Psi}(R(t)) \equiv \frac{r_{\delta} k_{0} k_{i} k_{s} N}{\alpha_{s}}-\gamma N w-\gamma R L-a y_{f}^{\phi}\left(\frac{w R^{\gamma_{s}}}{\beta_{s} A_{s} k_{s}^{\alpha_{s}} w_{s}^{\gamma_{s}}}\right)^{1-\varepsilon} .
\end{aligned}
$$

From (A11), we solve

$$
\bar{k}=\Psi(R) \equiv \frac{1}{\left(1+r^{*}\right) N}\left(\widetilde{\Psi}+\frac{r_{\delta} k_{s} \bar{\Psi}}{\alpha_{s} w_{s}}\right)\left(\gamma+\frac{\eta r_{\delta} k_{s}}{\alpha_{s} w_{s}}\right)^{-1} .
$$

By the following procedure we can determine all the variables as functions of $R: \bar{k}$ by (A12) $\rightarrow K$ by $(\mathrm{A} 11) \rightarrow p$ by $(\mathrm{A} 9) \rightarrow K_{i}$ and $K_{s}$ by $(\mathrm{A} 1) \rightarrow N_{i}$ and $N_{s}$ by (A1) $\rightarrow D_{T}$ by (8) $\rightarrow \hat{y}$ by $(\mathrm{A} 4) \rightarrow l, c, c_{s}, c_{Z}, s$ by $(13) \rightarrow L_{s}$ by $(15) \rightarrow F_{i}$ by $(1) \rightarrow F_{s}$ by (4).

From this procedure and (14), we have

$$
\dot{\bar{k}}=\Lambda(R) \equiv \lambda \hat{y}-\bar{k} \text {. }
$$

Taking derivatives of (A12) with respect to time yields

$$
\dot{\bar{k}}=\frac{d \Psi}{d R} \dot{R} \text {. }
$$

We do not provide the expression of $d \Psi / d R$ because it is tedious. Solve (A13) and (A14)

$$
\dot{R}=\bar{\Lambda}(R) \equiv \Lambda\left(\frac{d \Psi}{d R}\right)^{-1}
$$

We have thus proved the lemma. 


\section{REFERENCES}

Andereck, K.L.; Valentine, K.M.; Knopf, R.C.; Vogt, G.A. (2005) Residents' perceptions of community tourism impacts, Annals of Tourism Research, 32 (4), 1056-1076.

Antonakakis, N.; Dragouni, M.; Filis, G. (2015) How strong is the linkage between tourism and economic growth in Europe?, Economic Modelling, 44, 142-155.

Balaguer, L.; Cantavella-Jorda, M. (2002) Tourism as a long-run economic growth factor: The Spanish case, Applied Economics, 34, 877-884.

Baumol, W.J. (1967) Macroeconomics of unbalanced growth: The anatomy of urban crisis, American Economic Review, 57(3), 415-426.

Benigno, G.; Benigno, P. (2003) Price stability in open economies, Review of Economic Studies, 70, 743764.

Blake, A.; Sinclair, M.T.; Campos, J.A. (2006) Tourism productivity: Evidence from the United Kingdom, Annals of Tourism Research, 33, 1099-1120.

Chao, C.C.; Hazari, B.R., Laffargue, Y.P.; Yu, E. S.H. (2006) Tourism, Dutch disease and welfare in an open dynamic economy, Fapanese Economic Review, 57, 501-515.

Chao, C.C.; Hazari, B.R.; Laffargue, Y.P.; Yu, E. S.H. (2009) A dynamic model of tourism, employment, and welfare: The case of Hong Kong, Pacific Economic Review, 14, 232-245.

Chou, M.C. (2013) Does tourism development promote economic growth in transition countries? A Panel Data Analysis, Economic Modelling, 33, 226-232.

Copeland, B. R. (1991) Tourism, welfare and de-industrialization in a small open economy, Economica, 58, 515-529.

Copeland, B.R. (2012) Tourism and welfare-enhancing export subsidies, Fapanese Economic Review, 63, 232-243.

Corden, W.M.; Neary, J.P. (1982) Booming sector and de-industrialization in a small open economy, Economic Fournal, 92, 825-848.

Dritsakis, N. (2004) Tourism as a long-run economic growth factor: An empirical investigation for Greece using causality analysis, Tourism Economics, 10, 305-316.

Drubarry, R. (2004) Tourism and economic growth: The case of Mauritius, Tourism Economics, 10, 389-401. 
Dwyer, L.; Forsyth, P.; Spurr, R. (2004) Evaluating tourism's economic effects: New and old approaches, Tourism Management, 25, 307-317.

Eicher, T.S.; Schubert, S.F.; Turnovsky, S.J. (2008) Dynamic effects of terms of trade shocks: The impact on debt and growth, Fournal of International Money and Finance, 27, 876-896.

Frederick, S.; Loewenstein, G.; O’Donoghue, T. (2002) Time discontinuing and time preference: A critical review, Fournal of Economic Literature, 11, 317-336.

Gali, J.; Monacelli, T. (2005) Monetary policy and exchange rate volatility in a small open economy, Review of Economic Studies, 72, 707-734.

Gaŕin-Mũnos, T. (2007) German demand for tourism in Spain, Tourism Management, 28, 12-22.

Harberger, A.C. (1950) Currency depreciation, income, and the balance of trade, Fournal of Political Economy, 58, 47-60.

Hazari, B.R.; Lin, J.J. (2011) Tourism, terms of trade and welfare to the poor, Theoretical Economics Letters, 1, 28-32.

Hazari, B.R.; Sgro, P.M. (1995) Tourism and growth in a dynamic model of trade, fournal of International Trade and Economic Development, 4, 243-252.

Hazari, B.R.; Sgro, P.M. (2004) Tourism, Trade and National Welfare, Amsterdam, Elsevier.

Ikeda, S. (2001) Weakly non-separable preferences and the Harberger-Laursen-Metzler effect, Canadian Fournal of Economics, 34, 290-307.

Kim, H.J.; Chen, M.H.; Jang, S. (2006) Tourism expansion and economic development: The case of Taiwan, Tourism Management, 27, 925-933.

Kollmann, R. (2001) The Exchange rate in a dynamic-optimizing business cycle model with nominal rigidities: A quantitative Investigation, Fournal of International Economics, 55, 243-262.

Kollmann, R. (2002) Monetary policy rules in the open economy: Effects on welfare and business cycles, Fournal of Monetary Economics, 49, 899-1015.

Kose, M.A. (2002) Explaining business cycles in small open economies: How much do world prices matter?, Fournal of International Economics, 56, 299-327.

Lane, P.R. (2001) The new open economy macroeconomics: A survey, fournal of International Economics, 54, 235-266.

Lanza, A.; Temple, P.; Urga, G. (2003) The implications of tourism specialisation in the long run: An econometric analysis for 13 OECD economies, Tourism Management, 24, 315-321. 
Laursen, S.; Metzler, L.A. (1950) Flexible exchange rates and the theory of employment, Review of Economics and Statistics, 32, 281-299.

Luzzi, G.F.; Flückiger, Y. (2003) Tourism and international trade: Introduction, Pacific Economic Review, 8, 239-243.

Mansoorian, A. (1993) Habit persistence and the Harberger-Laursen-Metzler effect in an infinite horizon model, Fournal of International Economics, 34, 153-166.

Marin-Pantelescu, A.; Tigu, G. (2010) Features of the travel and tourism industry which may affect pricing, Fournal of Environmental Management and Tourism, 1, 8-11.

Matarrita-Cascante, D. (2010) Beyond growth: Reaching tourism-led development, Annals of Tourism Research, 32(4), 1141-1163.

Matsuyama, K. (1987) Current account dynamics in a finite horizon model, Fournal of International Economics, 23, 299-313.

Mendosa, E.G. (1995) The terms of trade, the real exchange rate, and economic fluctuations, International Economic Review, 36, 101-137.

Obstfeld, M. (1982) Aggregate spending and the terms of trade: Is there a Harberger-Laursen-Metzler effect?, Quarterly Fournal of Economics 97, 251-270.

Obstfeld, M.; Rogoff, K. (1996) Foundations of International Macroeconomics, Mass., Cambridge: MIT Press.

Oh, G.O. (2005) The contribution of tourism development to economic growth in the Korean economy, Tourism Management, 26, 39-44.

Sachs, J. (1982) The current account in the macroeconomic adjustment process, Scandinavian fournal of Economics, 84, 147-159.

Schubert, S. F.; Brida, J.G. (2009) A dynamic model of economic growth in a small tourism driven economy, Munich Personal RePEc Archive.

Svensson, L.E.O.; Razin, A. (1983) The terms of trade and the current account: The HarbergerLaursen-Metzler effect, Foumal of Political Economy, 91, 97-125.

Sinclair, M.T.; Stabler, M. (1997) The Economics of Tourism, London: Routledge.

Solow, R. (1956) A contribution to the theory of growth, Quarterly Fournal of Economics, 70, 65-94.

Stabler, M.J., Papatheodorou, A.; Sinclair, M.T. (2010) The Economics of Tourism, London: Routledge. 
Syriopoulos, T.C. (1995) A Dynamic model of demand for Mediterranean tourism, International Review of Applied Economics, 9, 318-336.

Turnovsky, S.J. (1996) Fiscal policy, growth, and macroeconomic performance in a small open economy, Foumal of International Economics, 40, 41-66.

Turnovsky, S.J.; Chattopadhyay, P. (2003) Volatility and growth in developing economies: Some numerical results and empirical evidence, Fournal of International Economics, 59, 267-295.

Uzawa, H. (1961) On a two-sector model of economic growth, Review of Economic Studies, 29, 47-70.

Zeng, D.Z.; Zhu, X.W. (2011) Tourism and industrial agglomeration, Fapanese Economic Review, 62, 537-561.

Zhang, W.B. (2005) Economic Growth Theory, London: Ashgate.

Zhang, W.B. (2008) International Trade Theory: Capital, Knowledge, Economic Structure, Money and Prices over Time and Space, Berlin: Springer.

Zhang, W.B. (2012) Tourism and economic structure in a small-open growth model, fournal of Environmental Management and Tourism, 3(2), 76-92. 